\title{
トップライト型ボイド空間における入射光による各階の日射負荷の推定 ESTIMATION OF THE SOLAR RADIATION LOAD AT EVERY FLOOR IN SKYLIGHTED VOID SPACE
}

\author{
菊田弘輝*, 泉孝典**, 羽山広文***, 絵内正道**** \\ Koki KIKUTA, Takanori IZUMI, Hirofumi HAYAMA \\ and Masamichi ENAI
}

\begin{abstract}
Recently, buildings that adopted the external insulation method that is possible to take the thick insulation are widely prevalent in cold regions. While the reduction of heating load in winter is generally expected, the increase of cooling load in summer is concerned. So, it is necessary to devise the buildings and facilities like natural ventilation and solar control. The aim of this paper is to estimate the solar radiation load at every floor caused by incident light in skylighted void space. Therefore, we calculate the solar irradiance using ideas of luminous efficacy about the illuminance from the illumination distribution to every floor, and show details of solar radiation load at every floor by model experiment and numerical analysis.
\end{abstract}

Keywords: Skylighted void space, Solar radiation load, Luminous efficacy トップライト型ボイド空間, 日射負荷, 発光効率

\section{1.はじめに}

現在，寒冷地を中心に厚い断熱が可能な外断熱工法を採用した建 物が広く普及してきている。一般的に冬期の暖房負荷の削減が期待 される一方，夏期の冷房負荷の増大が懸念されるため，自然換気（外 気冷房・夜間換気）や日射制御（日射遮蔽・昼光利用）等の建築的・ 設備的工夫が必要になる。自然換気においては換気経路の一部にボ イド空間を利用した事例が一般的である。また，日射制御において は側面空が中心である一方，ボイド空間に合わせて昼光利用を目的 にトップライトを設置した事例 1),2) が数多く見受けられる.

本研究ではトップライト型ボイド空間における熱・光環境計画に ついて取り上げるが，日射・採光に係る自然エネルギー利用の効果 として, ダイレクトゲインによる暖房負荷の削減や, 昼光利用によ る照明負荷の削減が期待できる。一方，透過日射による冷房負荷の 増大や, オーバーヒートやグレアの問題等が懸念され, 熱・光環境 の両者を考慮した開口計画が求められる ${ }^{3)}$. しかし, 本研究で取り上 げるトップライトからの入射光が及ぼす影響の中でも，熱環境への 影響度を推定することは困難である。事実，ボイド空間の最下層よ りも最上層の方が外界の影響を強く受けるため，ボイド空間の最上 層に隣接する居室空間の熱環境制御は容易ではない，更に，建築設 備設計基準 ${ }^{4)}$ の熱負荷計算の中でも，トップライトからの日射負荷 の内訳までは到底対応し切れていない. 熱・光環境の両者を考慮し た既往研究として, 宿谷 ${ }^{5)}$ のエクセルギー, 井上・一ノ瀬ら ${ }^{6)}$ の空・ 制御システム, 吉澤・武田ら ${ }^{7)}$ の熱負荷計算等が挙げられるが，卜 ップライトに関連する研究は非常に少なく, トップライト型ボイド 空間へ入射した光の挙動を正確に把握することは重要である.
本研究の目的は, トップライト型ボイド空間における入射光によ る各階の日射負荷を推定することである，具体的には，模型実験及 び数值解析により各階の照度分布から照度に関する発光効率の概念 を用いて日射量を算定し，各階の日射負荷の内訳を明らかにするこ とである。

\section{2. 模型実験}

\section{1 実験概要}

各階の日射負荷を推定する際に，直達光と天空光の性質が大きく 異なるため, 直達光の影響が大きい晴天日及び天空光の影響が大き い曇天日における各階の照度分布をそれぞれ明らかにする，想定し た建物・壁面形状を表 1 ，想定した太陽位置を表 2 に示す，照度に関 寸る影響因子として，建物形状や壁面形状等の建物因子（基準階高 さ $(\mathrm{H})$ ，トップライト・ボイド形状，反射率（ $\rho)$ ，立体角投射率 (U) ) 及び太陽位置や天候等の外界因子（太陽高度 (h), 太陽方位角 (A), 晴天指数 $\left.\left(\mathrm{K}_{\mathrm{Te}}\right)\right)$ が挙げられる.太陽高度と太陽方位角は北緯 30 $45^{\circ}$ 地点で，日射負荷の大きくなる $10 \sim 14$ 時における太陽位置を 想定した. $\mathrm{K}_{\mathrm{Te}}$ とは仮想大気圈外水平面全天日射量 $\left(\mathrm{I}_{0}\right)$ に対する水 平面全天日射量の比で，天空状態を表す指標である.

北海道大学工学部 $R$ 棟の屋上に, 1 フロア $40[\mathrm{~m}] \times 40[\mathrm{~m}]=1600\left[\mathrm{~m}^{2}\right]$ （ボイド空間 : 1 フロアの約 1/10 $\left(12.5[\mathrm{~m}] \times 12.5[\mathrm{~m}]=156.25\left[\mathrm{~m}^{2}\right]\right)$, 基準階高さ：約 $3.5[\mathrm{~m}]$ または約 $5.0[\mathrm{~m}]$ ）の複層オフィスビルを縮尺 $1 / 25$ 模型で再現した。計測階の平面図を図 1 , 模型全体の断面図を 図 2 に示寸。本実験は 2007 年 11 月に行われた。計測階である 1 フ ロアのみに照度ロガー（HIOKI 製 3640, 計 35 点）及び小型日射計（英

\footnotetext{
* 北海道大学大学院工学研究科 助教 $\cdot$ 博士 (工学

** (株)大林組

*** 北海道大学大学院工学研究科 教授 $\cdot$ 博士 (工学)

$* * * *$ 北海道大学 名誉教授. 工博
}

Assis. Prof., Graduate School of Eng., Hokkaido Univ., Dr. Eng.

Obayashi Corporation

Prof., Graduate School of Eng., Hokkaido Univ., Dr. Eng.

Prof. Emeritus, Hokkaido Univ., Dr. Eng. 
弘精機 ML-020VM，計 2 点）等を取り付けた．そのフロア中央点に対 するトップライトのUを, 想定する階のUと等しくすることで, 建 物内の各階を再現した。 U の変更には, 計測階上に外壁面や屋根面 を積み上げていく工夫を施した。また，想定した太陽位置には，模 型全体を傾斜させていく工夫を施した.

\section{2 実験結果}

代表点の照度分布を図 3 , 図 4 に示す。東京の夏至における南中 時 $\left(\mathrm{A}=0^{\circ}, \mathrm{h}=79^{\circ}\right), \mathrm{H}=139[\mathrm{~mm}], \rho=$ 天井面 $80[\%]$ ・ 壁面 $0[\%]$ ・ 床面 30 [\% ] の結果である. 晴天時には東西軸ボイドかつ U $=0.2$ の み模型中心 $(0,0)$ が計測可能であった。晴天時にはフロア中央点 に対して対称形であり, 指向性のない天空光のみが入射していたと

表 1 想定した建物・壁面形状

\begin{tabular}{|c|c|c|c|c|}
\hline $\begin{array}{c}\text { 基準階高さ } \\
\mathrm{H}[\mathrm{mm}] \\
\end{array}$ & $\begin{array}{l}\text { トップライト. } \\
\text { ボイド形状 }\end{array}$ & & [\%] & $\begin{array}{c}\text { 立体角投射率 } \\
\mathrm{U}[-]\end{array}$ \\
\hline \multirow{5}{*}{139} & \multirow{3}{*}{$\begin{array}{c}\text { 南北軸 } \\
\text { ボイド }\end{array}$} & 天井面 & $\begin{array}{ll}50 & 80 \\
\end{array}$ & \multirow{3}{*}{0.8} \\
\hline & & 壁面 & 0 & \\
\hline & & 床面 & $30 \quad 50$ & \\
\hline & \multirow{3}{*}{$\begin{array}{l}\text { 正方形 } \\
\text { ボイド }\end{array}$} & 天井面 & 5080 & \multirow[t]{2}{*}{0.6} \\
\hline & & 壁面 & 0 & \\
\hline \multirow[t]{4}{*}{202} & & 床面 & $\begin{array}{lll}10 & 30 & 50\end{array}$ & 0.4 \\
\hline & \multirow{3}{*}{$\begin{array}{l}\text { 東西軸 } \\
\text { ボイド }\end{array}$} & 天井面 & $\begin{array}{ll}50 & 80 \\
\end{array}$ & \multirow{3}{*}{0.2} \\
\hline & & 壁面 & 0 & \\
\hline & & 床面 & $30 \quad 50$ & \\
\hline
\end{tabular}

表 2 想定した太陽位置

\begin{tabular}{c|r|r|r|r|r|r|r|r}
\hline \\
\cline { 2 - 10 }
\end{tabular}

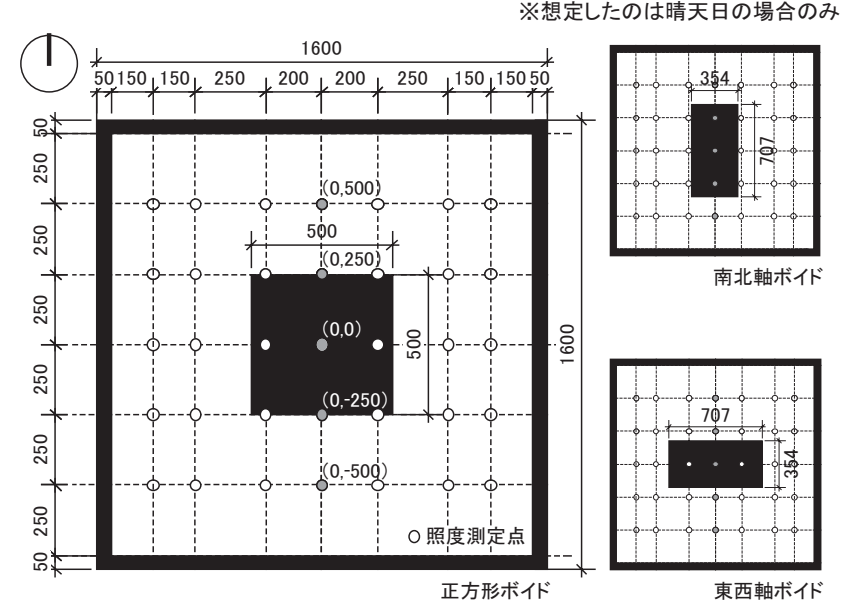

図 1 計測階の平面図

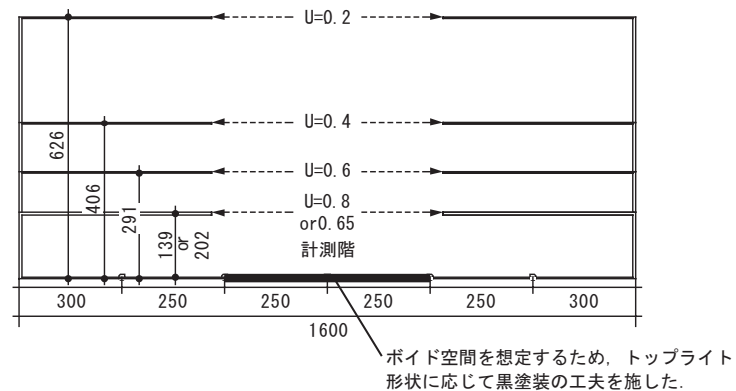

図 2 模型全体の断面図
判断できるため, 南北軸ボイドと東西軸ボイドは同等であると仮定 した，また，Uの変化による照度の減衰率が一定でないのは，測定 時期に応じて日射量や日射成分が異なったためである。

\section{3 解析}

\subsection{1 解析目的}

照度を構成する 4 要素を図 5 に示す. 解析目的は, 模型実験から 得られた照度を(1)〜 (4)に分解し，建物形状や壁面形状等の建物因子 や太陽位置や天候等の外界因子を関数とした任意の条件下における

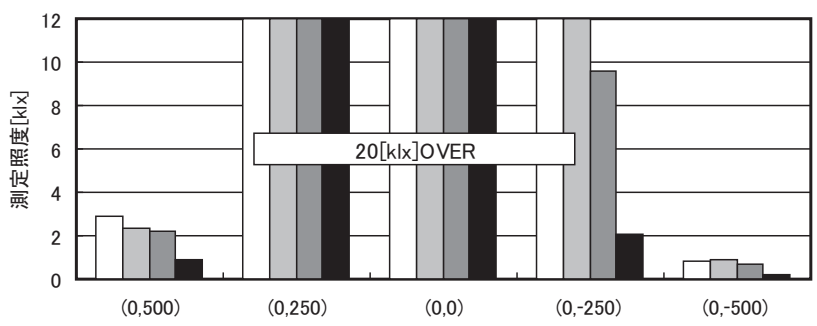
(a) 南北軸ボイド

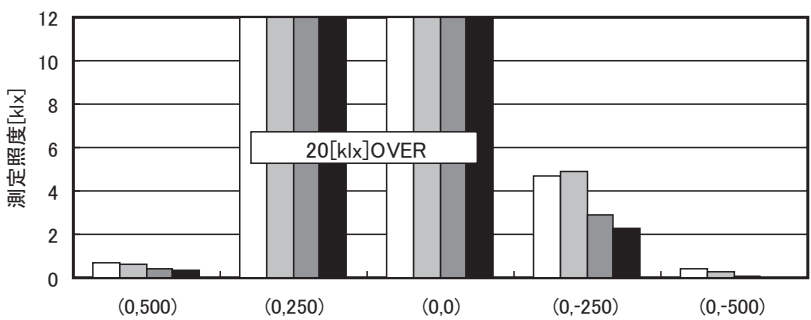

(b) 正方形ボイド

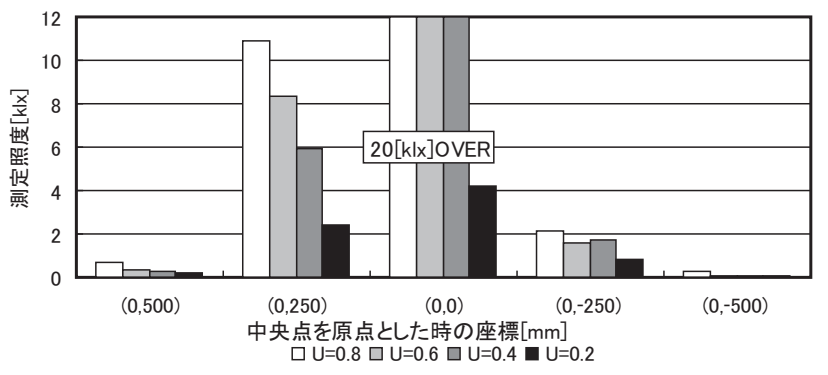

(c) 東西軸ボイド

図 3 代表点の照度分布（晴天時）

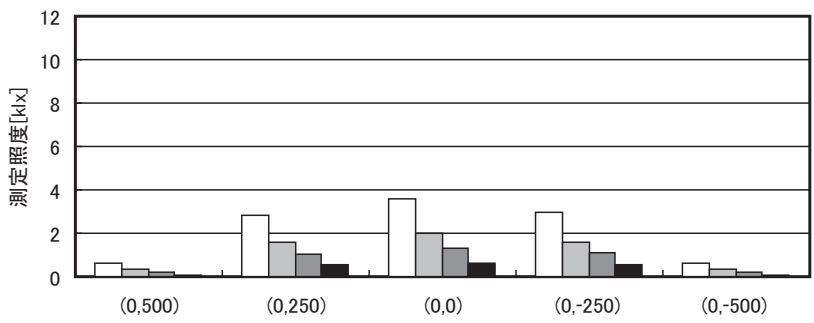

(a) 南北軸ボイド

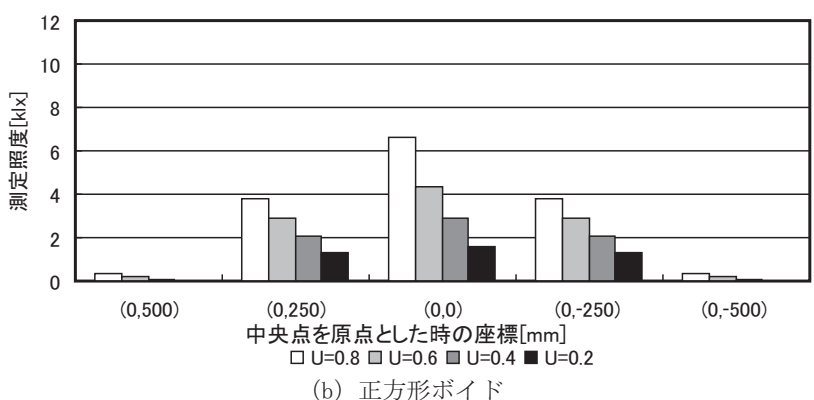

図 4 代表点の照度分布（曇天時） 
照度推定式を導くことである. また, 最も照度に影響を与えた建物 因子を探ることである，その手順を以下に示す。

【手順 1】発光効率の式を用いて, (1)直達光による直接照度と (3)天空 光による直接照度を導く.

【手順 2】天空成分のみが含まれる曇天時に測定された照度から，(3) を除くことで，(4)天空光による間接照度を導く

【手順 3】直達成分と天空成分が含まれる晴天時に測定された照度か らこれまでに導かれた (1)・(3)・(4)を除くことで，(2)直達光による 間接照度の推定式を導く.

\subsection{2 直散分離}

日射量は水平面及び模型屋上面の計 2 点で計測した。直散分離は 晴天指数（ $\mathrm{K}_{\mathrm{Te}}=0.77[-] ）$ を用いた分離式により行い，全天日射量 $\left(\mathrm{I}_{\mathrm{G}}\right)\left[\mathrm{W} / \mathrm{m}^{2}\right]$ から直達日射量 $\left(\mathrm{I}_{\mathrm{p}}\right)\left[\mathrm{W} / \mathrm{m}^{2}\right]$ と天空日射量（ $\left.\mathrm{I}_{\mathrm{S}}\right) \quad[\mathrm{W} /$ $\mathrm{m}^{2}$ ] を算出した ${ }^{8)}$. クラウド・レイシオ $\left(\mathrm{C}_{\mathrm{Re}}\right)$ とは全天日射量（ま たはグローバル照度)に対する天空日射量 (または天空照度)の比で, 天空状態を推測することができる.

$$
\begin{aligned}
& I_{D}=I_{G}-I_{S} \\
& I_{S}=I_{G} C_{\mathrm{Re}} \\
& C_{\mathrm{Re}}=0.98965+0.014886 K_{T e}+0.96096 K_{T e}^{2} \\
& \quad-8.2762 K_{T e}{ }^{3}+6.97074 K_{T e}{ }^{4}
\end{aligned}
$$

\section{3.3 天空光の挙動把握}

全天空照度（ $\mathrm{E}_{\mathrm{S}} ）[\mathrm{k} 1 \mathrm{x}]$ は全天空照度の発光効率 $\left(\eta_{\mathrm{s}}\right)[1 \mathrm{~m} / \mathrm{W}]$ あ るいは太陽高度（h） [ rad] の関数として表される ${ }^{9)}$. 測定時期の異 なる照度分布を同等に比較するため，(4) 式の $\mathrm{h}$ 及び $\mathrm{I}_{\mathrm{S}}$ に関する項 を揃え， $\mathrm{E}_{\mathrm{S}}$ 等しくした上でUの関数として整理した。

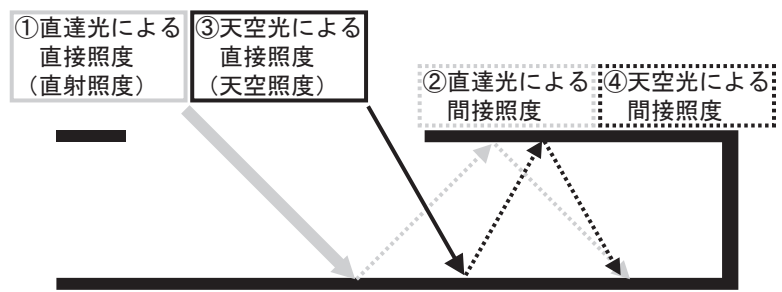

図 5 照度を構成する 4 要素

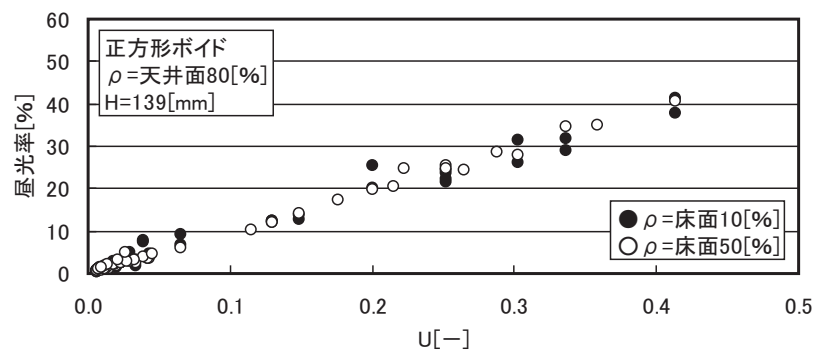

図 6 床面反射率の違いによる昼光率

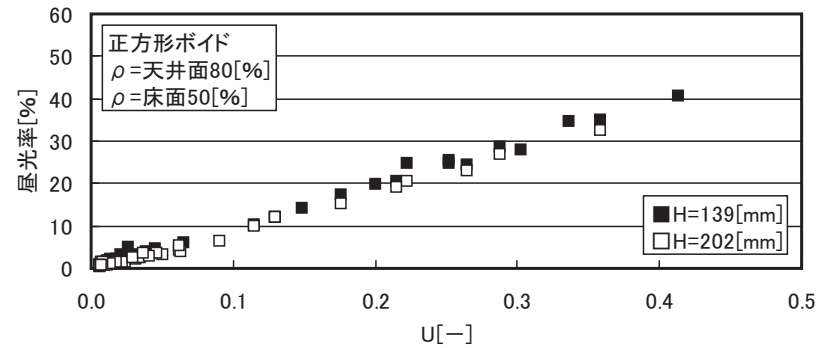

図 7 計測階高さの違いによる昼光率

$$
\begin{aligned}
E_{S} & =\eta_{S} I_{S} \\
& =\left(0.1794+0.1628 h-0.1389 h^{2}+0.0429 h^{3}\right) I_{S}^{0.9}
\end{aligned}
$$

床面反射率の違いによる昼光率を図 6 , 計測階高さの違いによる 昼光率を図 7 に示す．正方形ボイドから判断すると，床面反射率や 計測階高さの違いによる変化は殆ど見られず，天空光による間接照 度は無視できる範囲と考えられる，測定点の天空照度（E's） [k1x] は測定点に対するUを用いて算出する.

$$
E^{\prime}{ }_{S}=E_{S} U
$$

\section{3.4 直達光の挙動把握}

直射照度（ $\mathrm{E}_{\mathrm{p}} ）\left[\mathrm{k} 1 \mathrm{x}\right.$ ）は直射照度の発光効率（ $\eta_{\mathrm{D}} ）[1 \mathrm{~m} / \mathrm{W}]$ あるい は太陽高度（h） [ rad] の関数として表される ${ }^{9)}$. 測定時期の異なる 照度分布を同等に比較するため, (6) 式の $\mathrm{h}$ 及び $\mathrm{I}_{\mathrm{D}}$ に関する項を揃え， $\mathrm{E}_{\mathrm{D}}$ を等しくした上で $\mathrm{U}_{\mathrm{I}} \times \mathrm{U}_{\mathrm{S}}$ の関数として整理した.

$$
\begin{aligned}
E_{D} & =\eta_{D} I_{D} \\
& =\left(0.01184+0.06192 h-0.07127 h^{2}+0.02667 h^{3}\right) I_{D}{ }^{1.2}
\end{aligned}
$$

直達光による間接照度に関する指標 $\mathrm{U}_{\mathrm{I}} \times \mathrm{U}_{\mathrm{S}}$ を図 8 に示す. $\mathrm{U}_{\mathrm{I}}$ は直 達光受照面の天井投射面が測定点に放射する「光束の大きさ」を表 す指標， $\mathrm{U}_{\mathrm{S}}$ は測定点に対してある大きさの光束を放射する「領域の 広さ」を表す指標として設定した。

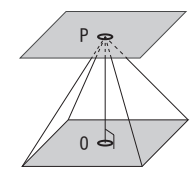

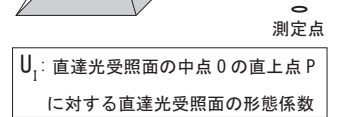

定点

に対する直達光受照面の形態係数

図 8 直達光による間接照度に関する指標 $\mathrm{U}_{\mathrm{I}} \times \mathrm{U}_{\mathrm{s}}$
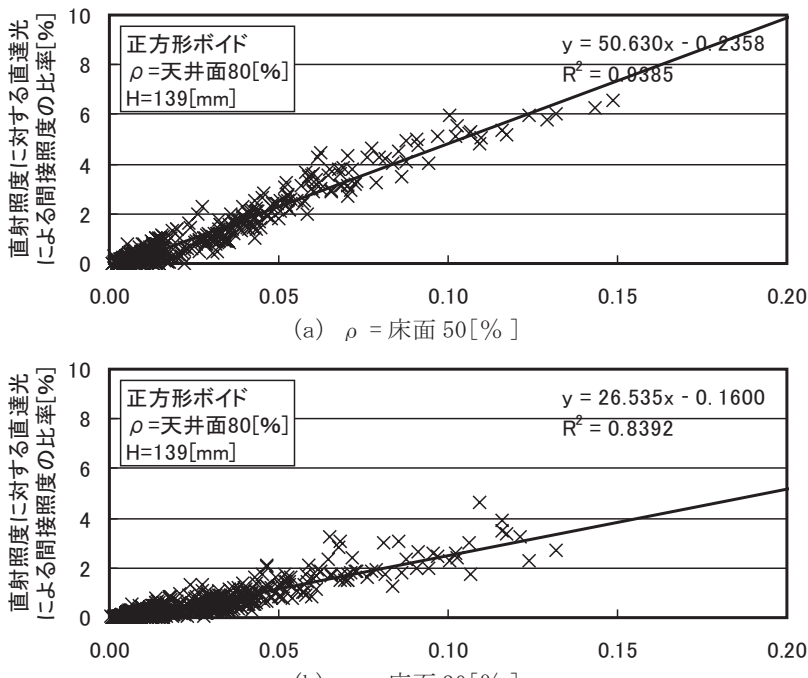

(b) $\rho=$ 床面 $30[\%]$

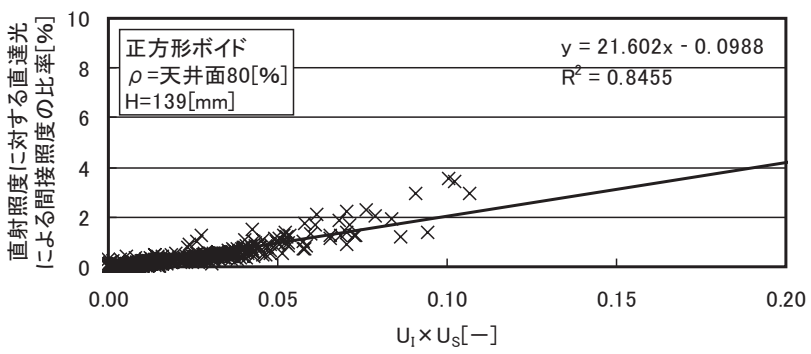

(c) $\rho=$ 床面 $10[\%]$

図 9 床面反射率の違いによる直射照度に対する 直達光による間接照度の比率 
床面反射率の違いによる直射照度に対する直達光による間接照度 の比率を図 9 に示寸. トップライト・ボイド形状や計測階高さの違 いによる差異は小さかったため, 正方形ボイド及び $\mathrm{h}=139[\mathrm{~mm}]$ から 判断すると, 天空光とは対照的に床面反射率の違いによる変化は顕 著であった，その床面反射率別の関係式を基に，新たに最小自乗近 似式を作成し，任意の条件下における照度推定式を導いた。測定点 の直達光による間接照度 $\left(\mathrm{E}^{\prime}{ }_{\mathrm{D}}\right)[\mathrm{k} 1 \mathrm{x}]$ は測定点に対する $\rho$ 及び $\mathrm{U}_{\mathrm{I}} \times$ U⿺尢丶用いて算出する.

$$
E_{D}^{\prime}=E_{D} \rho\left(1.0878 U_{I} \times U_{S}-0.0055\right)
$$

\section{3. 数值解析}

\section{1 汎用性の向上}

トップライト型ボイド空間における入射光による各階の日射負荷 を推定する上で, 汎用性のある気象データ（気象庁管理の気象台デ 一タ）の日射量を使用し，時刻毎におけるトップライトからの日射 負荷の内訳を明らかにしたい，先の模型実験により建物形状や壁面 形状等の建物因子の中で，最も照度に影響を与えた建物因子として， 床面反射率（ $\rho$ ） と立体角投射率 (U) であることが示唆された。こ のことを踏まえ， 2 つのパラメータに限定した模型実験を行った．

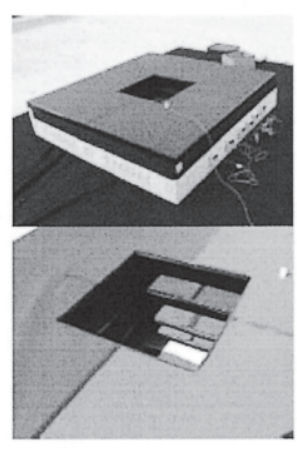

写真 1 模型写真

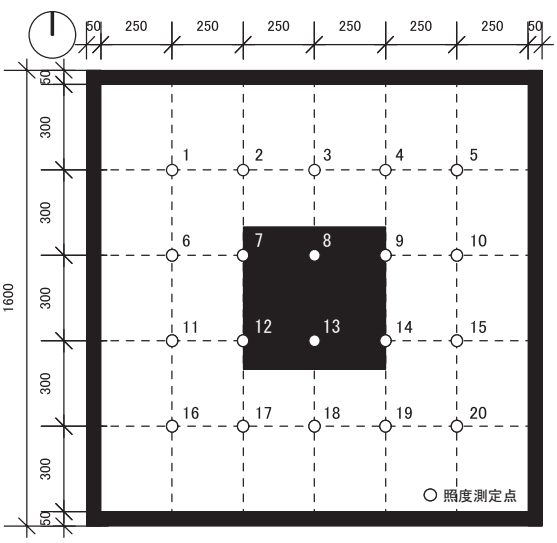

図 10 計測階の平面図

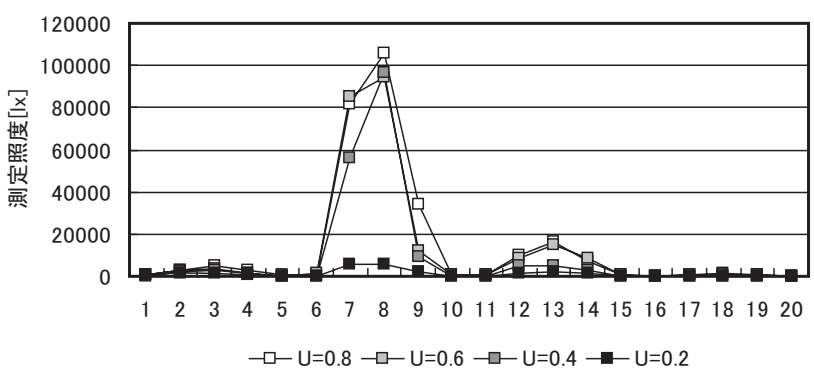

(a) $\rho=$ 床面 $50[\%]$
模型写真を写真 1，計測階の平面図を図 10 に示す。本実験は 2008 年 9 月に行われた。実験概要はほぼ共通しているが，一部変更点と して，照度測定点を等間隔（計 20 点）にした点と，模型を傾斜させ てある期間を断片的に測定する方法から，模型を傾斜させずに一定 期間を連続的に測定する方法にした点が挙げられる。続いて，この 模型実験と数值解析の結果を比較し，シミュレーションの信頼性を 実証することにした。

\section{2 信頼性の実証}

\section{2.1 実験結果}

パラメータ整理時の照度（模型実験）を図 11 に示寸。それぞれパ ラメータの変更に対応した照度の大小関係が確認され，これらの結 果を参考に，シミュレーションの環境設定を行った。

\subsection{2 解析概要}

シミュレーションの諸条件を入力する上で，事前に汎用性のある 気象データの日射量を直散分離 $\left((1) \cdot(2)\right.$ 式 $\left.^{8)}\right)$ し, 発光効率の式 を用いた照度変換（(4)・(5）式 $\left.{ }^{9)}\right)$ により直射照度と全天空照度を 算出する必要がある。因夕に，信頼性の実証における模型実験と数 值解析の結果を比較する際には模型屋上面の日射量を使用している. ただし，直散分離で用いられる $\mathrm{K}_{\mathrm{Te}}$ は，これまでの一定值から変動值 とし， $\mathrm{K}_{\mathrm{Te}}$ の条件に応じて $\mathrm{C}_{\mathrm{Re}}$ を算出した。

$$
\begin{aligned}
& K_{T e}=I_{G} / I_{0} \sinh \\
& 0 \leqq K_{T e} \leqq 0.81 \\
& C_{\mathrm{Re}}=0.98965+0.014886 K_{T e}+0.96096 K_{T e}{ }^{2} \\
& \quad-8.2762 K_{T e}^{3}+6.97074 K_{T e}{ }^{4}
\end{aligned}
$$

$0.81<K_{T e} \leqq 1.0$

$C_{\mathrm{Re}}=0.43438-0.28038 K_{T e}$

\subsection{3 模型実験と数值解析の比較}

模型実験と数值解析の比較（ $\rho=$ 床面 $50[\%$ ] ) を図 12 に示す。 直達光の影響が大きい測定点（7，8）では $120000[1 \mathrm{x}]$ ，小さい測定 点（1〜 5) では $6000[1 \mathrm{x}]$ の範囲で比較した結果，多少の誤差を考

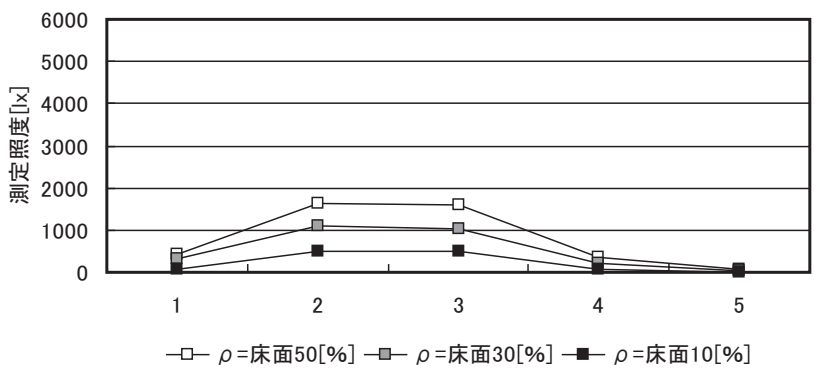

(b) $\mathrm{U}=0.2$

図 11 パラメータ整理時の照度（模型実験）

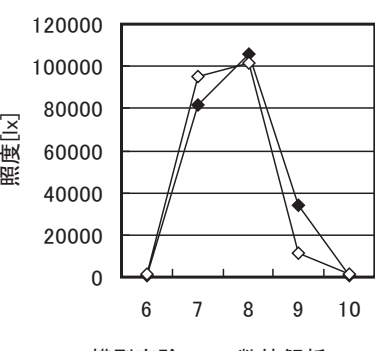

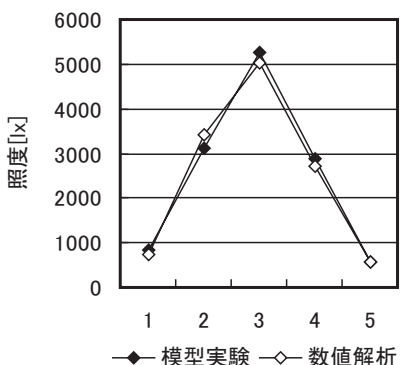

頃

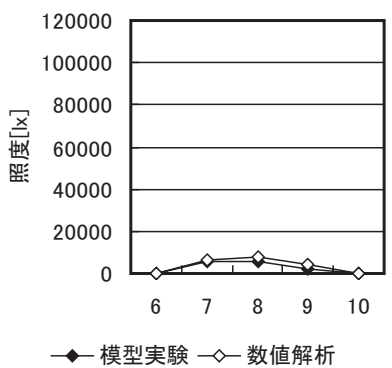

(b) U=0.2（9月 20 日 12:00 頃)

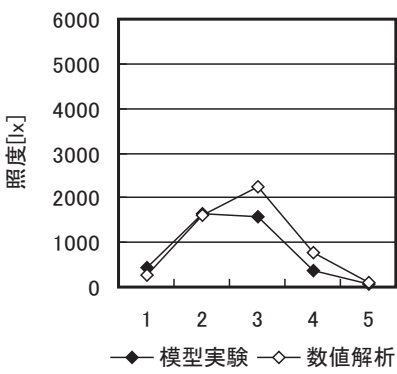

図 12 模型実験と数值解析の比較（ $\rho=$ 床面 $50[\%])$ 
慮すれば，ほぼ一致していたと判断できる. 以降，信頼性が実証さ れたこのシミュレーションの環境設定で, 仮想モデルを用いた感度 解析を行った.

\section{4. 仮想モデルを用いた感度解析}

\section{1 解析概要}

仮想モデルの断面図を図 13，アクソメを図 14 ，普通複層ガラスの

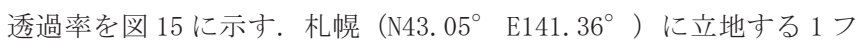
ロア $30[\mathrm{~m}] \times 30[\mathrm{~m}]$ (ボイド面積: $64\left[\mathrm{~m}^{2}\right], 81\left[\mathrm{~m}^{2}\right], 100\left[\mathrm{~m}^{2}\right]$, 正 方形ボイド）の 4 階建てオフィスビル ${ }^{10)}$ を対象に，トップライト型 ボイド空間における入射光による各階の日射負荷を推定した，ガラ ス構成はFL ガラス $3[\mathrm{~mm}]+$ 中空層 $6[\mathrm{~mm}]+\mathrm{FL}$ ガラス $3[\mathrm{~mm}]$ とし, トッ プライトからの採光を主体とした仮想モデルを作成するため, 側面 密面積は各面 28.8[ m²/階］と想定した.

\section{2 解析方法}

光環境シミュレーションソフト (Desktop Radiance 2.0) を数值 解析で使用し, 太陽光の設定では, 汎用性のある気象データの日射 量を用いた。 実際の天空状態を（a）〜（c）のように分類した，

(a) 量天空 $\cdots 0 \leqq \mathrm{~K}_{\mathrm{Te}} \leqq 0.3$

(b) 中間天空 $\cdots 0.3<\mathrm{K}_{\mathrm{Te}}<0.78$

(c) 晴天空 $\cdots 0.78 \leqq \mathrm{~K}_{\mathrm{Te}} \leqq 1.0$

シミュレーションの諸条件を入力した後, 出力された照度を(1)〜 (4)のように整理した.

(1) 直達光による直接照度 $\cdots(a-1)-(b-1)$

(2) 天空光による直接照度 $\cdots(b-1)$

(3) 直達光による間接照度 $\cdots((a-2)-(b-2))-((a-1)-(b-1))$

(4) 天空光による間接照度 $\cdots(b-2)-(b-1)$

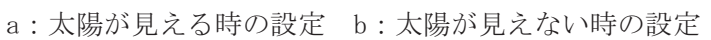

(a-1)，（b-1）: 建物の反射率を $0[\%]$ における照度

(a-2)，（b-2）：建物の反射率を x [\% ] における照度

各階の直接照度を用いて, 照度に関する発光効率から日射量を算 定し, 各階の直達光・天空光受照面積 $\left(\mathrm{S}_{\mathrm{D}} \cdot \mathrm{S}_{\mathrm{s}}\right) \quad\left[\mathrm{m}^{2}\right]$ における直達・ 天空日射負荷 $\left(Q_{D} ・ Q_{\mathrm{s}}\right) \quad[\mathrm{kWh}]$ を推定した。

$$
\begin{aligned}
& Q_{D}=S_{D} E_{D} / \eta_{D} \\
& Q_{S}=\sum S_{S} E_{S} / \eta_{S}
\end{aligned}
$$

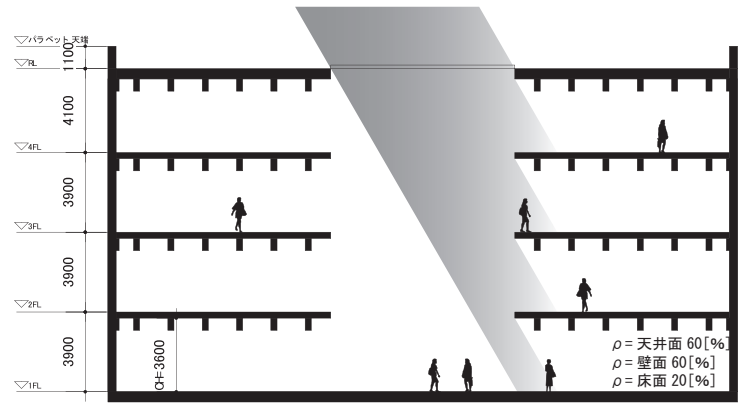

図 13 仮想モデルの断面図

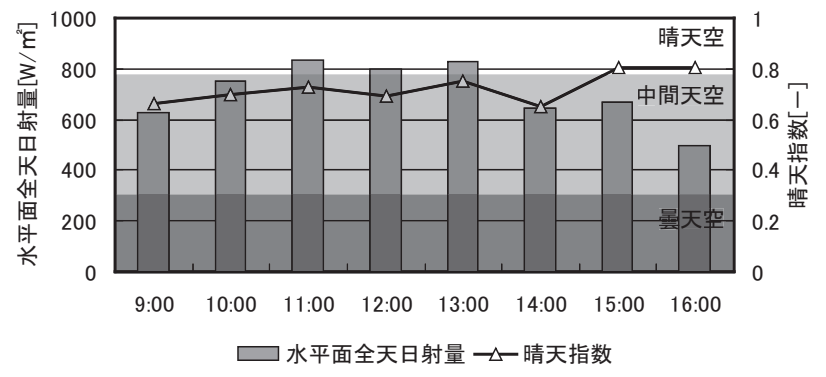

(a) 2007 年 8 月 12 日

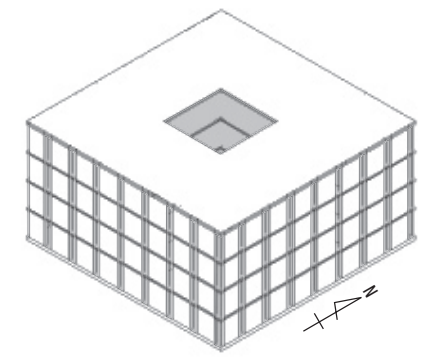

図 14 アクソメ

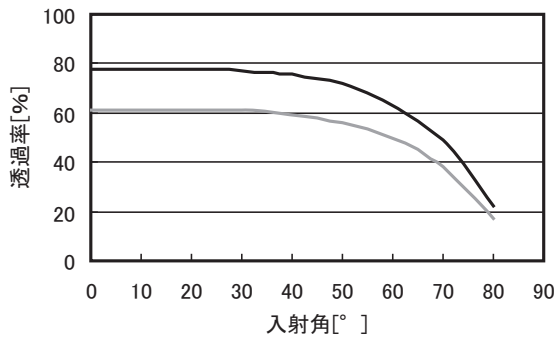

一可視光透過率 一 一射透過率

図 15 普通複層ガラスの透過率

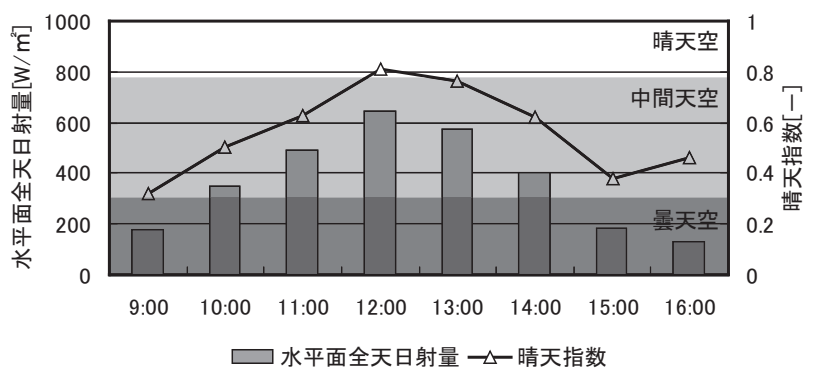

(b) 2008 年 2 月 24 日

図 16 水平面全天日射量と晴天指数

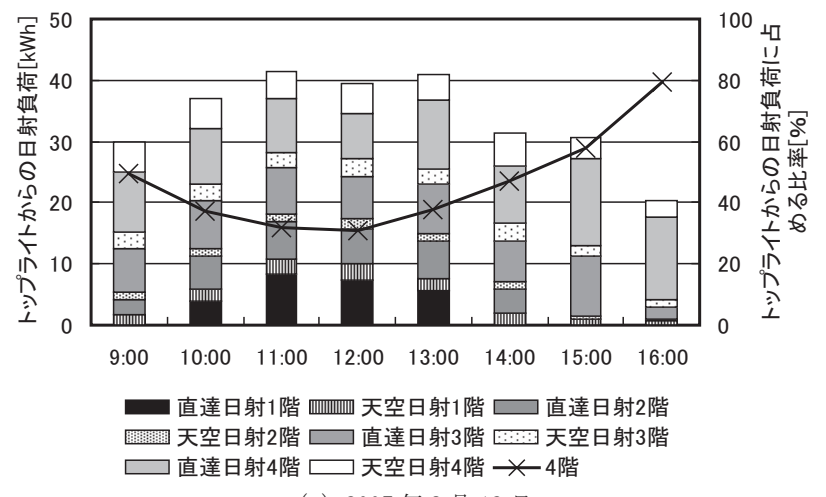

(a) 2007 年 8 月 12 日

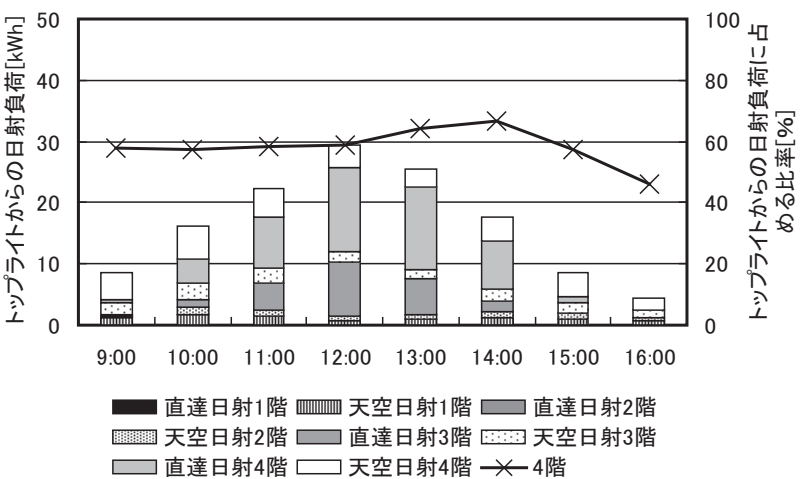

(b) 2008 年 2 月 24 日

図 17 トップライトからの日射負荷の内訳 $\left(81\left[\mathrm{~m}^{2}\right]\right)$ 


\section{3 解析結果}

水平面全天日射量と晴天指数を図 16, トップライトからの日射負 荷の内訳（81[ $\left.\mathrm{m}^{2}\right] ）$ を図 17 に示寸。太陽高度の高い夏期では，各 階に日射負荷が分散する傾向（4 階:約 30[\% ] ) を示した．その一方， 太陽高度の低い冬期や明方・夕方では，最上階に日射負荷が集中寸 る傾向（4階：約 60[\% ] ) を示した.

全日射負荷の内訳（81[ $\left.\mathrm{m}^{2}\right]$ ) を図 18 , ボイド面積別の単位床面 積当たりの日射負荷の内訳（4階）を図 19 に示す. ボイド面積 : 側 面空面積=約 1:6の条件では, トップライトからの日射負荷の比率 は 40[\%]以上（夏期），30[\% ] 前後（冬期）に達していた。また, ボイド面積を $64\left[\mathrm{~m}^{2}\right]$ と $100\left[\mathrm{~m}^{2}\right]$ に変更した場合, 面積比率に応じ て増減していた。晴天指数が比較的安定していた夏期では，太陽高 度が低くなる 14:00 以降に, 最上階の 4 階におけるトップライトか らの直達日射負荷が非常に大きくなった．同時に，この時間帯の側 面空からの直達日射負荷も当然大きくなり, 結果的に単位床面積当 たりの日射負荷が $40 〜 50\left[\mathrm{~W} / \mathrm{m}^{2}\right]$ になることが確認された

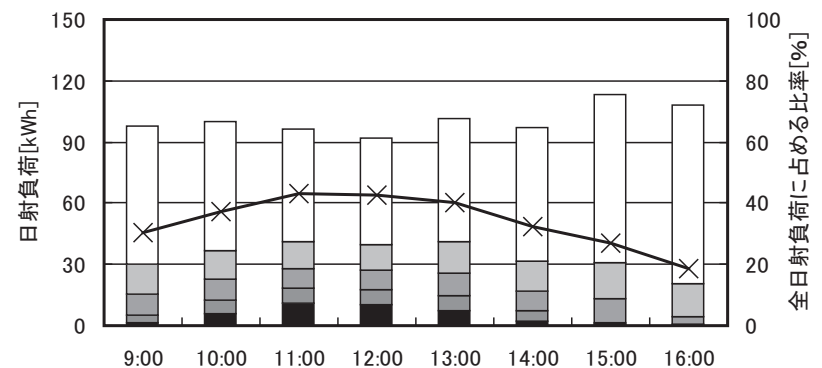

ロトップライトからの日射負荷1階 凹トップライトからの日射負荷 2 階 凹トップライトからの日射負荷3階 —トップライトからの日射負荷4階 —側面空からの日射負荷1４階 ー ×トップライト

(a) 2007 年 8 月 12 日
ボイド面積別のトップライトからの日射負荷の内訳（12:00）を図 20 に示す. ボイド面積を仮に $64\left[\mathrm{~m}^{2}\right]$ から $100\left[\mathrm{~m}^{2}\right]$ に拡大寸ると, 下階に配分される比率が増大し，夏期では約 33[\% ～(1 階)，冬期 では 38.1[\% ］（3 階）まで到達し，15[\% ］程度増加することが確 認された。

5.まとめ

トップライト型ボイド空間における入射光による各階の日射負荷 を推定した。以下に，得られた成果を簡潔にまとめる.

1）照度に関寸る発光効率の概念を用いて，トップライトからの入射 光が及ぼす光環境への影響度（各階の照度分布）から熱環境への 影響度（各階の日射負荷）を推定する方法を提案した。

2）模型実験により建物形状や壁面形状等の建物因子及び太陽位置や 天候等の外界因子を関数とした任意の条件下における照度推定式 を導き,最も照度に影響を与えた建物因子として, 床面反射率 $(\rho)$ と立体角投射率（U) であることを示した。

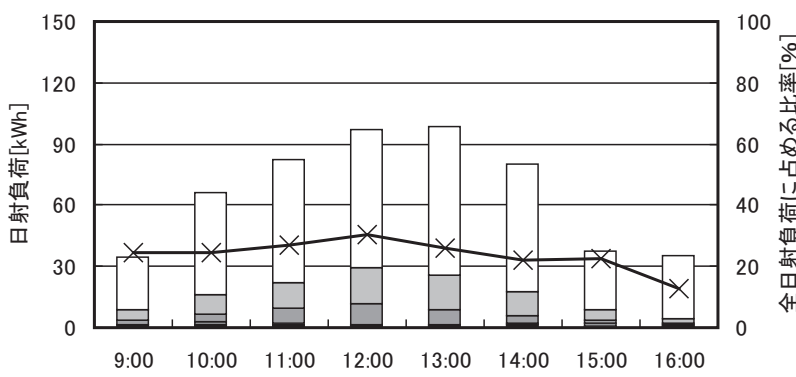

ートップライトからの日射負荷1階 ロトップライトからの日射負荷2階 凹トップライトからの日射負荷3階 —トップライトからの日射負荷4階 —側面空からの日射負荷1 4階 ー ヒトップライト

(b) 2008 年 2 月 24 日

図 18 全日射負荷の内訳 $\left(81\left[\mathrm{~m}^{2}\right]\right)$

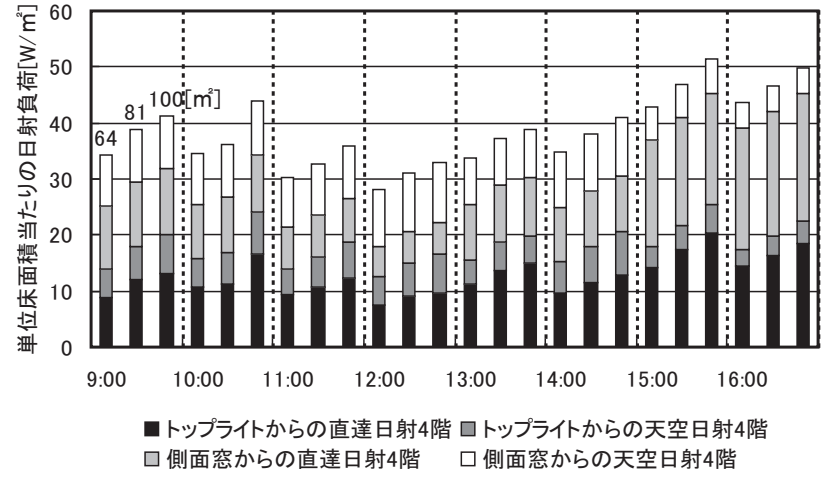

(a) 2007 年 8 月 12 日

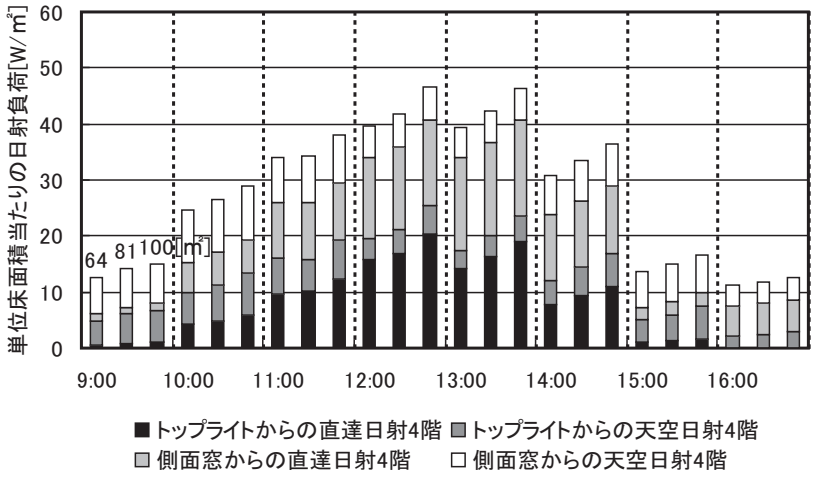

(b) 2008 年 2 月 24 日

2007 年8月 12 日

図 19 ボイド面積別の単位床面積当たりの日射負荷の内訳（4階）

\begin{tabular}{|c|c|c|c|}
\hline \multicolumn{4}{|c|}{$797\left[\mathrm{~W} / \mathrm{m}^{2}\right]$} \\
\hline 全階 & $31.12[\mathrm{kWh}]$ & $\downarrow$ & $100.0[\%]$ \\
\hline 4階 & $10.44[\mathrm{kWh}]$ & $64\left[\mathrm{~m}^{2}\right]$ & 33.5 [\%] \\
\hline 3階 & $7.71[\mathrm{kWh}]$ & & 24.8 [\%] \\
\hline 2階 & $6.56[\mathrm{kWh}]$ & & 21.1 [\%] \\
\hline 1階 & $6.41[\mathrm{kWh}]$ & & 20.6 [\%] \\
\hline
\end{tabular}

2008年2月24日

$647\left[\mathrm{~W} / \mathrm{m}^{2}\right]$

\begin{tabular}{|c|c|c|c|}
\hline 全階 & $23.18[\mathrm{kWh}]$ & $\downarrow$ & $100.0[\%]$ \\
\hline 4階 & $16.34[\mathrm{kWh}]$ & $64\left[\mathrm{~m}^{2}\right]$ & $70.5[\%]$ \\
\hline 3階 & $5.87[\mathrm{kWh}]$ & & 25.3 [\%] \\
\hline 2階 & $0.44[\mathrm{kWh}]$ & & $1.9[\%]$ \\
\hline 1階 & $0.53[\mathrm{kWh}]$ & & $2.3[\%]$ \\
\hline
\end{tabular}

(a) $64\left[\mathrm{~m}^{2}\right]$

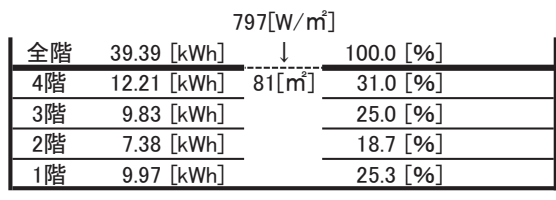

$647\left[\mathrm{~W} / \mathrm{m}^{2}\right]$

\begin{tabular}{|c|c|c|c|}
\hline 全階 & $29.34[\mathrm{kWh}]$ & $\downarrow$ & 100.0 [\%] \\
\hline 4階 & $17.30[\mathrm{kWh}]$ & $81\left[\mathrm{~m}^{2}\right]$ & $59.0[\%]$ \\
\hline 3階 & $10.55[\mathrm{kWh}]$ & & 36.0 [\%] \\
\hline 2階 & $0.65[\mathrm{kWh}]$ & & $2.2[\%]$ \\
\hline 1階 & $0.84[\mathrm{kWh}]$ & & $2.9[\%]$ \\
\hline
\end{tabular}

(b) $81\left[\mathrm{~m}^{2}\right]$

$797\left[\mathrm{~W} / \mathrm{m}^{2}\right]$

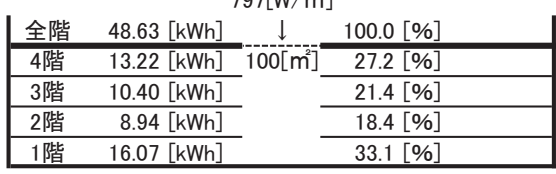

$647\left[\mathrm{~W} / \mathrm{m}^{2}\right]$

\begin{tabular}{|c|c|c|c|}
\hline 全階 & $36.22[\mathrm{kWh}]$ & $\downarrow$ & $100.0[\%]$ \\
\hline 4階 & $20.35[\mathrm{kWh}]$ & $100\left[\mathrm{~m}^{2}\right]$ & $56.2[\%]$ \\
\hline 3階 & $13.79[\mathrm{kWh}]$ & & $38.1[\%]$ \\
\hline 2階 & $0.89[\mathrm{kWh}]$ & & $2.5[\%]$ \\
\hline 1階 & $1.20[\mathrm{kWh}]$ & & $3.3[\%]$ \\
\hline
\end{tabular}

(c) $100\left[\mathrm{~m}^{2}\right]$

図 20 ボイド面積別のトップライトからの日射負荷の内訳（12:00） 
3）シミュレーションの信頼性を実証した後, 汎用性のある気象デー タの日射量を使用し, 時刻毎におけるトップライトからの日射負 荷の内訳を明らかにした。特に夏期の最上階における日射負荷は $40 \sim 50\left[\mathrm{~W} / \mathrm{m}^{2}\right]$ になり, ボイド面積の変更に伴い, 下階に配分さ れる比率が $15[\%]$ 程度増加し, 季節間の違いも確認された。

\section{謝辞}

本研究の一部は, 平成 $19 \sim 20$ 年度科学研究費補助金 (若手研究 (B)) 「高断熱事務所建物に適用可能な水方式による躯体蓄熱暖冷房システ 么の提案・開発」（研究代表者：菊田弘輝）により行った。 また，卒 業生の伊藤匡貴氏（東京工業大学）には多大なご協力を頂いた。記 して感謝する.

\section{本研究に関連した既発表文献}

*1) 菊田弘輝, 羽山広文, 絵内正道, 伊藤匡貴 : 断熱建物におけるトップライ 卜型ボイド空間の熱・光環境計画に関する研究その 3 数值解析における 入射光による各階の日射負荷の推定，太陽／風力エネルギー講演論文集 2009，投稿済，2009. 11

*2) 菊田弘輝, 羽山広文, 絵内正道, 伊藤匡貴 : トップライト型ボイド空間に おける各階の日射負荷の推定に関する分析と評価，空気調和・衛生工学会 学術講演会講演論文集, pp. 345-348, 2009.9

*3）伊藤匡貴，菊田弘輝，絵内正道，羽山広文：トップライト型ボイド空間に おける各階日射負荷推定手法に関する研究, 空気調和 ・ 衛生工学会北海道 支部 第 43 回学術講演会論文集, pp. 7-10，2009. 3

菊田弘輝, 泉孝典, 絵内正道, 羽山広文: 断熱建物におけるトップライ

*4）下型ボイド空間の熱・光環境計画に関する研究 その 2 模型実験における 入射光による各階の日射負荷の推定，太陽/風力エネルギー講演論文集 2008, pp. 229-232，2008. 11

*5) 泉孝典, 絵内正道, 羽山広文, 菊田弘輝：トップライト型ボイド空間を対
象とした光・熱環境計画に関する研究 その 1 模型実測による各階におけ る直達日射の挙動推定, 日本建築学会大会学術講演梗概集 環境工学 II （中 国)，pp. 27-28，2008.9

*6) 泉孝典, 菊田弘輝, 絵内正道, 羽山広文 : トップライト型ボイド空間を対 象とした光・熱環境計画に関する研究 その 1 模型実測による各階の天空 日射負荷の推定, 空気調和・衛生工学会北海道支部 第 42 回学術講演会論 文集，pp. 123-126，2008.3

\section{参考文献}

1) 大成札幌ビル：作品選集 2008 建築雑誌増刊, 社団法人日本建築学会, pp. 26-27, 2008. 3

2) 北海道立北方建築総合研究所：作品選集 2004 建築雑誌増刊，社団法人日 本建築学会, pp. 32-33, 2004.3

3）社団法人日本建築学会 : 昼光照明デザインガイド 自然光を楽しむ建築の ために，技報堂出版㑣，2007.8

4）社団法人公共建築協会：国土交通省大臣官房官庁営繥部設備・環境課監修 建築設備設計基準 平成 18 年版, 財団法人全国建設研修センター, 平成 19 年 5 月

5）宿谷昌則：数値計算で学ぶ光と熱の建築環境学，丸善侏，1993.7

6）一ノ瀬雅之，井上隆，関佑介，横田雄史：建築と設備が一体化したペリメ 一タレス空調システムの性能および省エネルギー効果の実測評価，日本建 築学会環境系論文集，No. 639，pp. 651-658，2009.5

7）吉澤望，武田仁，近藤純一：日射遮蔽物の入射角特性を考慮した熱負荷計 算 内付けブラインドの光学特性計算への Radiance の適用, 日本建築学会 環境系論文集，No. 640，pp. 675-684，2009.6

8）稲沼實，武田仁：長期観測デー夕に基づく日射の直散分離に関する実証的 研究，日本建築学会環境系論文集，No. 575，pp. 41-46，2004.

9）稲沼實，武田仁：長期観測デー夕に基づく昼光の発光効率に関する実証的 研究，日本建築学会環境系論文集，No. 560，pp.7-13，2002.10

10）菊田弘輝，泉孝典，絵内正道，羽山広文：断熱建物におけるトップライ 卜型ボイド空間の熱・光環境計画に関する研究 その 1 入射光による各階 の日射負荷の推定，太陽／風力エネルギー講演論文集 2007，pp. 321-324， 2007. 1 